\title{
MEMBEDAH TUJUAN PENDIDIKAN MUHAMMADIYAH
}

\author{
Mohamad Ali \\ Sekolah Dasar Muhammadiyah Program Khusus Surakarta \\ E-Mail: mohamadalisdmuhpk@ymail.com
}

\begin{abstract}
The presence of modern religious school "Muhammadiyah" (1911) be a trigger as the establishment of modern organizations: Muhammadiyah (1912). Long time before Indonesia's independence, Muhammadiyah has formulated educational goals for schools which are built.Since its establishment until today, the purpose of Muhammadiyah education amended several times. These changes are a creative response of Muhammadiyah on current social change, a shift in the orientation of community life, as well as the progress of science and technology.from the political constellation of national education, Muhammadiyah was relatively autonomous when formulating the educational goals. Meanwhile, from the perspective of modern educational theory, style of Muhammadiyah educational purposes closer to progressive education theory that emphasizes the experience reconstruction continuously as a vehicle to promote social life.
\end{abstract}

Keywords: educational; Muhammadiyah education; progressive.

\begin{abstract}
Abstrak: Kehadiran sekolah agama modern "Muhammadiyah" (1911) menjadi trigger berdirinya organisasi modern: Muhammadiyah (1912). Jauh sebelum Indonesia merdeka, Muhammadiyah telah merumuskan tujuan pendidikan bagi sekolah-sekolah yang diselenggarakannya. Sejak awal berdiri hingga saat ini, tujuan pendidikan Muhammadiyah mengalami beberapa kali perubahan. Perubahan-perubahan itu merupakan respons kreatif Muhammadiyah atas arus perubahan sosial, pergeseran orientasi kehidupan masyarakat, maupun kemajuan ilmu dan teknologi. Dilihat dari konstelasi politik pendidikan nasional, Muhammadiyah ternyata relatif mandiri ketika merumuskan tujuan pendidikannya. Sedangkan dari perspektif teori pendididkan modern, corak tujuan pendidikan Muhammadiyah lebih mendekati teori pendidikan progresif yang menekankan pada rekonstruksi pengalaman secara terus-menerus sebagai wahana memajukan kehidupan sosial.
\end{abstract}

Kata Kunci: tujuan pendidikan; pendidikan Muhammadiyah; progresif.

\section{PENDAHULUAN}

Keterkaitan Muhammadiyah dengan dunia pendidikan terasa begitu spesial dan unik. Di satu sisi Muhammadiyah bukanlah gerakan pendidikan, akan tetapi manifestasi gerakannya yang paling menonjol dan mengakar justru bidang pendidikan. Secara normatif-konseptual, identitas atau ciri khas Muhammadiyah dialamatkan pada gerakan Islam, gerakan dakwah, dan gera- kan tajdid ${ }^{1}$. Dan, bila ditengok ke belakang, KH Ahmad Dahlan membuka lembaga pendidikan terlebih dahulu, dan baru kemudian diikuti dengan berdirinya persyarikatan Muhammadiyah. KH Ahmad Dahlan

1 A.R. Fakhruddin, Muhammadiyah menuju masa mendatang. Yogyakarta: Persatuan, 1985; Sudarno shobron dkk., Studi Kemuhammadiyahan. Surakarta: LPIK UMS, 2014, hlm. 80-82; Musthafa Kamal Pasha dan Ahmad Adaby Darban, $M u$ hammadiyah sebagai gerakan Islam dalam perspektif historis dan ideologis. Yogyakarta: LPPI, 2000, hlm. 113-116. 
membuka sekolah agama modern bernama Madrasah Ibtidaiyah Diniyah Islamiyah pada Desember 1911 yang merupakan cikal bakal atau embrio pendidikan Muhammadiyah di kemudian hari. Kehadiran sekolah agama modern inilah yang kemudian menginspirasi Kyai Dahlan untuk mendirikan organisasi modern sebagai payung untuk melindungi dan menjaga keberlanjutan sekolah agama modern yang baru didirikannya itu, sehingga tahun 1912 berdirilah organisasi modern bernama: Muhammadiyah.

Berdasarkan rentetan peristiwa historis di atas, dapat diketahui bahwa kelahiran persyarikatan Muhammadiyah didorong oleh kebutuhan, dan terinspirasi, untuk dapat mengembangkan tata kelola pendidikan yang baik dan berkelanjutan. Melalui instrumen organisasi, sekolah agama modern yang baru berdiri itu tidak bernasib layaknya pesantren, yang umumnya meredup begitu kyai pendirinya meninggal dunia. Kehadiran organisasi juga dapat memanggil dan menggerakkan partisipasi publik secara seluas untuk terlibat aktif dalam amal Muhammadiyah. Dari sini dapat diketahui bahwa ketika mendirikan persyarikatan Muhammadiyah yang terorganisasi secara moderen itu, KH Ahmad Dahlan telah berpikir visioner-antisipatoris yang merupakan aktualisasi dari kesadaran bahwa amal sholeh (amal yang berkualitas) niscaya terus mengalir dan berkelanjutan (amal jariyah, amal yang tidak terputus meski yang bersangkutan meninggal dunia).

Pemikiran visioner-antisipatoris Kyai Dahlan menemukan bumi berpijaknya dalam Muhammadiyah. Pasca kepemimpinan Kyai Dahlan, organisasi ini terus tumbuh dan berkembang. Ruang lingkup dan wilayah gerak Muhammadiyah sebagai gerakan Islam, gerakan dakwah, dan gerakan tajdid tidak terbatas dalam bidang pendidikan. Ketika bagian-bagian (belakangan disebut majelis) didirikan tahun 1917, ada empat majelis yang paling awal berdiri yaitu bagian sekolahan, bagian pustaka, bagian tabligh, dan bagian penolong kesengsaraan umum (PKU). Peristiwa sejarah itu menunjukkan bahwa sejak awal Muhammadiyah begitu giat dan mengutamakan pendidikan, karena pendidikan dalam makna seluas-luasnya merupakan kunci kemajuan dan kegemilangan suatu bangsa (masyarakat, kaum, negara).

Derap langkah amal pendidikan $\mathrm{Mu}$ hammadiyah telah melewati lima lintasan zaman dengan seluruh lika liku yang mengiringinya; mulai era penjajahan Belanda, era pendudukan Jepang, era orde lama, era orde baru, dan era roformasi saat ini. Pendidikan Muhammadiyah mampu berjalan tegak melintasi zaman. Padahal, setiap era melahirkan tantangan yang berbeda-beda, sehingga untuk mengatasinya membutuhkan kejelian. Begitu banyak lembaga maupun organisasi pendidikan yang seusia dengan Muhammadiyah, bahkan jauh lebih muda, yang bertumbangan karena tidak kuat menghadapi gulungan ombak kehidupan.

Merujuk pada alur pemikiran di muka, dapat diajukan hipotesis bahwa salah satu rahasia sukses ketangguhan pendidikan Muhammadiyah menangkal mara bahaya dan goncangan sosial-ekonomi-politik karena keluasan, kedalaman dan keluwesan cita-cita atau tujuan pendidikan yang dikembangkangkannya. Bertolak dari hipotesis tersebut, tulisan ini berikhtiar untuk mendokumentasikan, menelaah dan merefleksikan tujuan pendidikan Muhammadiyah. Telaah demikian sangat kritikal karena beririsan dengan upaya pengungkapan dinamika inti (faktor dinamis) yang menggerakkan pendidikan Muhammadiyah selama ini. Sebab, tujuan pendidikan menggariskan secara ideal sekaligus praktikal apa saja yang hendak dicapai suatu lembaga pendidikan ${ }^{2}$. Dalam konteks rentangan waktu masa lalu, masa kini, dan masa depan, dapat diketahui bahwa wajah pendidikan Muhammadiyah saat ini sesungguhnya merupakan cita-cita atau tujuan pendidikan di masa lalu. Demikian pula rumusan tujuan pendidikan generasi sekarang ini akan terwujud di masa depan.

2 Imam Barnadib, Beberapa hal tentang pendidikan. Yogyakarta: Studing, 1982, hlm. 13. 
Tentu dengan catatan ada kegigihan untuk mewujudkan tujuan pendidikan yang dicita-citakannya itu.

Kajian tentang tujuan pendidikan $\mathrm{Mu}-$ hammadiyah belum banyak dilakukan oleh para peneliti. Hanya saja, penelitian tentang pemikiran pendidikan Muslim dari sudut teori pendidikan modern telah dilakukan Muhammad Jawwad Ridla. Menurutnya ada tiga aliran utama pemikiran pendidikan, yaitu: konservatif, religius-rasional, dan pragmatis ${ }^{3}$. Sebagaian besar tokoh pendidikan Muslim cenderung pada posisi dua aliran yang pertama, satu-satunya yang beraliran pragmatis-progresif adalah Ibnu Khaldun. Menarik untuk dicermati lebih jauh, kesimpulan penelitian Mohamad Ali atas pemikiran pendidikan $\mathrm{KH}$ Ahmad Dahlan yang menempatkannya pada aliran/ mazhab pendidikan progresif-religius ${ }^{4}$. Secara historis, rumusan tujuan pendidikan Muhammadiyah dilakukan pertama kali tahun 1936, jauh setelah pendiri Muhammadiyah meninggal dunia tahun 1923. Masih setiakah tujuan pendidikan Muhammadiyah dengan cita-cita pendirinya? Bagaimanakah posisi tujuan pendidikan Muhammadiyah dalam konstelasi politik pendidikan nasional?

\section{METODE PENELITIAN}

Sebagaimana telah terurai di bab pendahuluan, kajian ini berupaya mendokumentasikan, menalaah dan merefleksikan tujuan pendidikan Muhammadiyah dari masa ke masa dengan kerangka referensi teori pendidikan progresif John Dewey. Sesuai dengan fokus kajiannya, maka metode penelitian yang digunakan adalah metode historis/sejarah ${ }^{5}$.

3 Muhammad Jawad Ridla, Tiga aliran utama teori pendidikan Islam (Terjemahan: Mahmud Arif). Yogyakarta: Tiara Wacana, 2002.

4 Mohamad Ali, Paradigma pendidikan berkemajuan: Teori dan praksis pendidikan progresif religius KH Ahmad Dahlan. Yogyakarta: Suara Muhammadiyah, 2016.

5 Penjelasan dan kerangka kerja metode atau metodologi sejarah, lihat: Kuntowijoyo, metodologi sejarah, Yogyakarta: Tiara Wacana, 2003; Helius
Secara operasional langkah-langkah penelitian sebagai berikut. Pertama, heuristik yaitu pelacakan sumber-sumber sejarah tentang tujuan pendidikan Muhammadiyah. Kedua, kritik sumber sejarah yang diperoleh, sehingga yang disajikan benar-benar sumber yang andal dan terpercaya. Ketiga, mensintesiskan dan menginterpretasikan sumber-sumber yang otentik dengan kerangka referensi pendidikan progresif. Terakhir, menyajikan dalam bentuk tulisan (historiografi).

Pendekatan yang digunakan dalam penelitian ini adalah pendekatan sejarah. Nata, ${ }^{6}$ menyatakan bahwa historis atau see jarah adalah suatu ilmu yang di dalamnya dibahas berbagai peristiwa dengan memperhatikan unsur tempat, waktu, obyek, latar belakang, dan pelaku dari peristiwa tersebut. Pendekatan lain dalam penelitian ini adalah pendekatan biografi, Komarud$\operatorname{din}^{7}$ beralasan karena memaparkan tentang pemikiran atau pun pandangan tokoh, agamawan, politikus, ataupun sejarawan. Selain itu, penulis juga memakai pendekatan normatif, yaitu untuk merumuskan kesimpulan-kesimpulan mengenai keadaan dan kaidah yang berlaku pada obyek penelitian.

Sumber data primer diperoleh langsung dari subyek penelitian dengan mengenakan alat pengukur atau alat pengambilan data langsung pada subyek sebagai sumber informasi yang dicari. Teknik analsis datanya menggunakan Content analysis, sebagaimana ungkapan Suryabrata ${ }^{8}$ bahwa conten analysis adalah menganalisis data sesuai dengan kandungan isinya. Dengan ini data-data yang penulis kumpulkankan adalah bersifat deskriptif dan data tekstual yang

Sjamsuddin, metodologi sejarah, Yogyakarta: Ombak,2012; Sartono Kartodirdjo, Pendekatan ilmu sosial dalam metodologi sejarah, Jakarta: Gramedia, 1992; Louis Gottschalk, Mengerti sejarah (terjemahan: Nuhroho Notosusanto), Jakarta: UI Press, 2008.

6 Abuddin Nata, Metodologi Studi Islam, Jakarta: Raja Grafindo Persada, 1998. hlm. 59.

7 Komaruddin, Metode Penelitian Kualitatif, Yogyakarta: Pustaka Pelajar, 1991, hlm. 72.

8 Sumardi Suryabrata, Metode Penelitian, Jakarta: Rajawali Press, 1998, hlm. 94. 
bersifat fenomenal, maka dalam mengelola data-data tersebut penulis menggunakan analisis ini.

Dengan analisis ini penulis akan melakukan analisis data secara ilmiah dan menyeluruh tentang konsepsi dan pemikiran Ahmad Dahlan sebagai pendiri dan konseptor gerakan Muhammadiyah, yaitu dengan cara: a) komparatif, b) deskriptif, dan c) induktif. Selanjutnya, karena penelitian ini merupakan studi tokoh dan sejarah, maka langkah-langkah yang digunakannya meliputi: a) pemilihan topik, b) pengumpulan sumber, c) verifikasi (kritik sejarah, keabsahan sumber), d) interpretasi (analisis dan sintesis), e) historiografi atau penulisan, dan $\mathrm{f}$ ) penyimpulan.

\section{HASIL PENELITIAN DAN PEMBAHA- SAN}

\section{Dimensi tujuan dalam pendidikan}

Tujuan pendidikan merupakan das solen yang hendak dicapai melalui proses dan praktik pendidikan. Tujuan pendidikan berkaitan dengan perubahan yang diharapkan pada peserta didik setelah mengalami proses pendidikan, baik terkait dengan perkembangan pribadi maupun kehidupan sosial di mana individu itu berada. Dalam kajian pendidikan, perbincangan tentang tujuan pendidikan termasuk bagian dari ilmu pendidikan sistematis. Faktor-faktor pendidikan yang dikaji ilmu pendidikan sistematis mencakup: faktor tujuan, faktor pendidik, faktor anak didik, faktor alatalat, dan faktor alam sekitar. Pendidikan sistematis adalah uraian tentang pemikiran yang tersusun dengan lengkap mengenai masalah-masalah pendidikan. ${ }^{9}$

Masalah tujuan pendidikan merupakan permasalahan yang sangat mendasar dalam pendidikan yang merupakan intisari atau saripati pendidikan, sehingga keberdaannya jauh lebih penting dari gedung maupun perlengkapan lainnya. Seorang ulama yang menaruh perhatian besar pada masalah

9 Sutari Imam Barnadib, Pengantar ilmu pendidikan sistematis. Yogyakarta: Andi Offset, 1993, hlm. 17. pembinaan generasi muda, Muhammad Quthb membuka bukunya dengan pertanyaan, atau semacam dilema, lebih utama alat (sarana) dan atau tujuan. Meski tidak dijawab secara eksplisit, namun Quthb menekankan keniscayaan tujuan ${ }^{10}$. Sebab, alat ataupun sarana bisa berubah setiap saat, sedangkan tujuan relatif tahan lama. masalah alat atau sarana menjadi lebih jelas dan terarah ketika rumusan tujuan pendidikannya sudah dirumuskan. Senada dengan Quthb, Jules Payot, pedagog Prancis, sebagaimana dipertajam Crijns dan Reksosiswojo menandaskan bahwa: soal-soal pendidikan yang terkecilpun tak akan dapat kita pecahkan, kalau tidak diketahui di mana letaknya tujuan hidup dan untuk apa anak-anak dididik $^{11}$. Payot maupun Quthb menekankan urgensi tujuan, karena tujuan pendidikan berhimpitan dengan tujuan hidup dan bersentuhan dengan ke arah mana pendidikan anak-anak akan dilabuhkan.

Brubacher menandaskan setidaknya ada tiga fungsi tujuan dalam proses pendidikan, yaitu: memberi arah dalam proses pendidikan, memotivasi atau menjadi energi penggerak dalam mewujudkan nilai-nilai/cita-cita yang hendak dituju, dan menjadi kriteria untuk mengevaluasi proses pendidikan ${ }^{12}$. Dari sini kita tidak bisa membayangkan bila proses pendidikan tidak memiliki tujuan; ia akan berjalan tanpa arah dan haluan, para pelaku pendidikan dan warga belajar tidak termotivasi maupun kekurangan energi untuk berjalan ke arah cita-cita, dan tidak memiliki acuan atau kriteria untuk menilai kembali perjalanan proses pendidikannya, sehingga yang terjadi adalah pendidikan abal-abal yang tidak jelas ujung pangkalnya.

Tujuan pendidikan yang dimaksudkan

10 Muhammad Quthb, Sistem pendidikan Islam (Terjemahan Salman Harun), Bandung: Al-Maarif, 1984, hlm. 17.

11 Crijns dan Reksosiswojo, Pengantar di dalam praktik pengajaran dan pendidikan. Jakarta: Noordhoff-Kolff, 1952, hlm. 26.

12 John S. Brubacher, Modern philosophies of education. New York-London-Toronto: McGraw-Hill Book Company, 1969, hlm. 95. 
dalam perbincangan ini adalah tujuan pendidikan umum (akhir, total, lengkap) dalam kategori Langeveld ${ }^{13}$, yaitu tujuan pendidikan yang menjiwai segala tingkah laku perbuatan mendidik dalam setiap kondisi dan situasi dan harus diperhatikan pada setiap tempat serta di mana saja proses pendidikan di laksanakan ${ }^{14}$. Secara teknis tujuan umum menjadi arah dan acuan pengambil kebijakan, birokrat pendidikan, pimpinan sekolah, dan guru-guru ketika melangsungkan proses belajar mengajar di kelas. Artinya tujuan umum perlu diturunkan dan diterjemahkan sesuai dengan tujuan pendidikan khusus, misalnya terkait jenjang pendidikan. Atau, di turunkan ke dalam masing-masing mata pelajaran.

Proses perumusan tujuan pendidikan mempertimbangkan berbagai hal yang begitu rumit dan kompleks, sehingga perubahan di satu titik akan mempengaruhi titik-titik lain yang pada ujungnya mengubah formulasi tujuan pendidikannya. George R. Knigth memberi gambaran kompleksitas perumusan tujuan sebagai berikut: secara umum ada dua faktor dominan, yaitu faktor filsafat atau pandangan hidup yang relatif permanen dan faktor kontekstual yang relatif mudah berubah. Fakor filsafat meliputi keyakinan metapisik (misalnya: religius atau sekuler), keyakinan aksiologik, dan keyakinan epistemologik. Sedangkan konteks meliputi: dinamika politik, kondisi ekonomi, kekuatan sosial, dan harapan dari keluarga dan masyarakat. Konteks persekolahan juga turut menyumbang, seperti pemikiran guru, kondisi peserta didik, orientasi kurikulum dan lain-lain ${ }^{15}$. Dari penjelasan Knight dapat diketahui bahwa untuk memahami dan membedah tujuan pendidikan bukan perkara mudah. Karena membaca

13 Langeveld mengkategorikan tujuan pendidikan menjadi enam jenis, yaitu: tujuan umum, tujuan khusus/insidental, tujuan seketika, tujuan sementara, tujuan tidak lengkap, dan tujuan perantara.

14 Ali Saifullah, Pendidikan pengajaran dan kebudayaan. Surabaya: Usaha Nasional, 1982, hlm. 77.

15 George R. Knight, Issues and alternative in educational philosophy. Michigan: Andrews University Press, 1982, hlm. 33. rumusan tujuan pendidikan bukan sekedar daftar keinginan dan harapan, atapun pandangan hidup, tapi hal itu harus diselaraskan dengan konteks sosial-ekonomi-politik yang seolah-olah berada di luar pendidikan, namun sesungguhnya sangat berpengaruh terhadap proses pendidikan itu sendiri.

Tujuan pendidikan bersentuhan langsung dengan, atau merupakan manifestasi dari, pandangan hidup seseorang atau suatu bangsa. Oleh karena pandangan hidup setiap bangsa berbeda-beda, maka sudah sepantasnya bila tiap negara-bangsa memiliki tujuan yang berbeda-beda senafas dengan keragaman tujuan maupun pandangan hidupnya. Bahkan di dalam suatu bangsa bisa melahirkan beragam tujuan pendidikan, karena memiliki fokus dan penekanan yang berbeda dalam penyelenggaraan pendidikannya, seperti halnya tujuan pendidikan Muhammadiyah, sebagai suatu komunitas dan organisasi sosial-keagamaan yang berada dalam wilayah Negara kesatuan republik Indonesia.

Ragam rumusan tujuan pendidikan itu diberi ruang yang luas, asalkan tidak bertentangan dengan tujuan pendidikan nasional dan fondasi negara: Pancasila. Contoh tujuan pendidikan yang bertentangan dengan Pancasila adalah pendidikan komunis yang melahirkan manusia ateis, atau pendidikan ultra-nasionalis (transnasional) yang mencita-citakan mendirikan Negara sendiri di dalam Negara Kesatuan Republik Indonesia (NKRI). Di luar itu, pendidikan swasta baik yang berlandaskan agama maupun nasionalis diberi ruang yang luas oleh Negara sebagai bentuk partisipasi masyarakat dalam ikut serta mencerdaskan bangsa. Pendidikan yang diselenggarakan Muhammadiyah harus dibaca sebagai bentuk partisipasi masyarakat dalam mencerdaskan kehidupan bangsa.

\section{Tujuan Pendidikan dalam perspektif teori pendidikan modern}

Sebagaimana dijelaskan di muka, untuk memaknai tujuan pendidikan Muhammadiyah digunakan kerangka referensi teori pendidikan modern, khususnya teori pen- 
didikan progresif. Oleh karena itu, berikut dijelaskan secara singkat tujuan pendidikan dari beragama filsafat ataupun teori pendi- dikan moderen. Secara ringkas, konsep tujuan pendidikan menurut pandangan teori pendidikan ditapilkan tabel 1 di bawah ini.

Tabel 1. Tujuan Pendidikan Menurut Teori Pendidikan Moderen

\begin{tabular}{|c|c|c|}
\hline Akar Filsafat & Teori & Tujuan \\
\hline Idealisme & $\begin{array}{l}\text { Perenialisme: } \\
\text { education as } \\
\text { cultural regression }\end{array}$ & $\begin{array}{l}\text { Untuk mendidik peserta didik menjadi } \\
\text { manusia rasional (rational person); kembali } \\
\text { ke jiwa Abad Pertengahan sebagai dasar } \\
\text { intelektual manusia. }\end{array}$ \\
\hline $\begin{array}{l}\text { Idealisme dan } \\
\text { Realisme }\end{array}$ & $\begin{array}{l}\text { Esensialisme: } \\
\text { education } \\
\text { as cultural } \\
\text { conservation }\end{array}$ & $\begin{array}{l}\text { Untuk mendidik menjadi manusia yang } \\
\text { cakap dan berguna; perantara nilai yang } \\
\text { ada di dalam gudang di luar ke dalam diri } \\
\text { anak. }\end{array}$ \\
\hline Pragmatisme & $\begin{array}{l}\text { Progresivisme: } \\
\text { education as } \\
\text { cultural transition }\end{array}$ & $\begin{array}{l}\text { Untuk mendidik individu sesuai minat } \\
\text { dan kebutuhan anak; rekonstruksi } \\
\text { pengalaman secara terus-menerus, } \\
\text { sehingga tumbuh menjadi pribadi } \\
\text { inteligen yang terlibat aktif dalam } \\
\text { pemecahan masalah-masalah kehidupan } \\
\text { sosial yang dihadapi. }\end{array}$ \\
\hline
\end{tabular}

Sumber: Diolah dan dikembangkan oleh penulis dari Ornstein \& Levine (1989: 89); Imam Barnadib (1994: 25); Brameld (1955: 123-158)

Dalam kajian teori pendidikan, setidaknya dikenal tiga teori pendidikan moderen yang popular, yaitu: perenialisme, esensialisme, dan progresivisme ${ }^{16}$, sebagaimana disajikan secara ringkas dalam tabel 1. Bertolak dari pendekatan kebudayaan, Brameld menjelaskan bahwa orientasi pendidikan perenialisme adalah regresif yang ingin kembali dan mempertahankan nilainilai dan idea-idea besar Abad Pertengahan,

16 Theodore Brameld, Philosophies of education in cultural perspective. New York \& London, Holt-Rinehart-Winston; Imam Barnadib, Filsafat pendidikan: Pengantar mengenai system dan metode. Yogyakarta: Andi Offset Yogyakarta, 1994, hlm. 24-27. Untuk rumusan tujuan pendidikan para pendidik muslim, lihat: Muhammad Jawad Ridla, Tiga aliran utama teori pendidikan Islam. Terjemahan Mahmud Arif. Yogyakarta: Tiara Wacana, 2002; Ali Al Jumbulati, Perbandingan pendidikan Islam. Jakarta: Rineka Cipta, 1994; Abd. Rachman Assegaf, Aliran pemikiran pendidikan Islam. Jakarta: Rajawali Pers, 2013. di mana tujuan pendidikan adalah untuk melahirkan manusia rasional (intelektual). Berbeda dengan perenialisme yang berorientasi regresif, orientasi pendidikan esensialisme bersifat konservatif. Tujuan pendidikan adalah mempertahan nilia-nilai agung-luhur yang telah bertahan lama dalam masyarakat. Oleh karena itu, tugas pendidikan adalah memindahkan nilai-nilai luhur itu ke dalam diri anak-peserta didik sehingga dapat hidup dalam masyarakat konservatif dengan nilai-nilai luhur yang dijunjung tinggi.

Terakhir, progresivisme yang orientasi pendidikannya berbeda dengan perenialis yang regresif maupun esensialis yang konservatif. Progresivisme berorientasi pada kemajuan (progress) di mana tujuan pendidikan harus mempertimbangkan minat anak. Tujuan pendidikan progresif adalah untuk melahirkan manusia yang inteligen (cerdas), yaitu manusia yang secara pribadi 
tumbuh utuh segala potensinya dan terus tumbuh kemampuannya karena digunakan untuk memahami dan memecahkan permasalahan sosial secara terus-menerus. Singkatnya, tujuan pendidikan menurut kaum progresif adalah rekonstruksi pengalaman secara terus-menerus.

Perlu dijelaskan perbedaan antara manusia rasional yang dicita-citakan pendidikan perenialis dengan dengan konsep manusia inteligen yang dicita-citakan pendidikan progresif. Manusia rasional adalah manusia yang mampu memahamai dan mengunyah karya-karya besar dari penulis Abad Pertengahan. Sedangkan manusia inteligen (cerdas) berkaitan dengan kemampuannya dalam memahami dan memecahkan permasalahan sosial yang membelit dirinya maupun lingkungan sosil masyarakat yang luas. Kehidupan sosial akan bergerak maju setapak demi setapak apabila permasalahan kehidupan sosial itu bisa dipecahkan. Namun karena permasalahan kehidupan selalu muncul dan bertambah kompleks, maka usaha dan perjuangan memecahkan kehidupan sosial tidak pernah mengenal kata akhir (finish). Dengan jalan problem solving inilah kehidupan sosial akan bergerak maju, sebaliknya bila terlalu benyak permasalahan kehidupan yang tak terselasaikan maka kehidupan sosial berjalan di tempat, atau bahkan mengalami kemunduran dan kehancuran.

\section{Dinamika Tujuan Pendidikan Muham- madiyah}

Sebagaimana disinggung di atas, rumusan cita-cita ataupun tujuan pendidikan mencerminkan dimensi yang kompleks dan sangat luas, kesadaran ini penting ditekankan ketika menelusuri tujuan pendidikan di lingkungan persyarikatan Muhammadiyah. Dalam tinjauan sosio-historis, tujuan pendidikan Muhammadiyah tidak bisa dilepaskan dari dinamika kebangsaan. Secara garis besar, perkembangan atau dinamika tujuan pendidikan Muhammadiyah dapat dipilah menjadi dua zaman, yaitu era pra-perumusan dan era perumusan formal. Di era pra-perumusan, tujuan pendidikan sudah ada tetapi belum dirumuskan secara eksplisit dan formal, karena tujuan persyarikatan masih menyatu dengan tujuan pendidikannya, dan penjelasan langsung dari $\mathrm{KH}$ Ahmad Dahlan dapat menjadi petunjuk/ haluan ke arah mana orientasi tujuan pendidikan Muhammadiyah. Dengan kata lain, pada era pra-perumusan tujuan pendidikan sudah ada, hanya saja belum dirumuskan secara formal dan eksplisit.

Dalam pandangan $\mathrm{KH}$ Ahmad Dahlan, tujuan pendidikan: dadiyo kyai sing kemajuan, lan aja kesel-kesel anggonmu nyambut gawe kanggo Muhammadiyah ${ }^{17}$, terjemahan dalam bahasa Indonesia kurang lebih: jadilah ulama yang berkemajuan, dan tidak kenal lelah bekerja/beramal bagi Muhammadiyah. Kata-kata Kyai Dahlan tersebut dapat diinterpretasikan bahwa tujuan pendidikan Muhammadiyah menurutnya adalah untuk mewujudkan dan menumbuhkan manusia religius, orang Islam yang menguasai "ilmu-ilmu agama" maupun "ilmu-ilmu umum" sekaligus di mana secara individual seluruh potensi/fitrahnya tumbuh optimal sehingga bisa menjadi pribadi yang cerdas (inteligen), yaitu pribadi yang bersedia berjuang atau bekerja untuk memecahkan masalah-masalah sosial-kemasyarakatan dan menggerakkan ke arah kemajuan (progress). Dengan demikian, secara singkat kyai berkemajuan adalah ulama yang bersedia terlibat dan mampu memecahkan permasalahan sosial-kehidupan yang dihadapi masyarakat. Karena kebenaran agama maupun ilmu dalam pandangan kyai Dahlan harus diuji secara "pragmatis", yaitu kegunaan secara fungsional untuk memecahkan problematika kehidupan yang muncul silih berganti.

Interpretasi di atas menemukan titik persinggungannya dengan tujuan persyarikatan, yang pada era ini juga menjadi tujuan pendidikan Muhammadiyah. Untuk lebih jelasnya berikut kutipan tujuan yang

17 Amir Hamzah Wirjosukarto, Pembaharuan pendidikan dan pengajaran Islam yang diselenggarakan oleh pergerakan Muhammadiyah. Yogyakarta: Penyelenggara publikasi pebaharuan pendidikan/pengajaran Islam, 1962, hlm. 58. 
telah direvisi.

Tujuan Muhammadiyah Rumusan 1921:

1. Memajukan dan menggembirakan pengajaran dan pelajaran agama Islam di Hindia Nederland.

2. Memajukan dan menggembirakan cara kehidupan sepanjang kemauan agama Islam kepada Lid-lidnya (segala sekutunya $)^{18}$.

Membaca dan menginterpretasikan rumusan tujuan di atas harus secara historis-kontekstual. Istilah pengajaran, dari kata dasar pengajar (pendidik-kyai-ulama-cendekiawan-intelektual), sedangkan istilah pelajaran berasal dari kata dasar pelajar (peserta didik-santri-mahasiswa). Berangkat dari pemahaman istilah itu dapat disimpulkan bahwa pimpinan, warga, maupun simpatisan Muhammadiyah saat itu dapat dipilah menjadi dua, yaitu pengajar-pelajar yang tengah berupaya keras untuk mengkaji atau belajar Islam dalam suasana penuh kegembiraan dan secara berkemajuan. Suasana belajar menggembirakan bila tidak ada tekanan, kekerasan maupun paksaan. Kegembiraan muncul ketika semua partisipan (warga belajar) dapat menyampaikan ide-idenya dengan penuh tanggung jawab dan belajar sesuai minatnya. Pada titik ini, gagasan gerakan intelektual dari A. Syafii Maarif, maupun gagasan pengilmuan Islam dari Kuntowijoyo dalam lingkungan Muhammadiyah memiliki landasan historis yang kokoh, karena gerakan Muhammadiyah awal merupakan gerakan pembelajaran dan pembelajaran masyarakat/publik yang berdimensi luas.

Istilah memajukan sebagai anti-tesis keterbelakangan kaum muslim-pribumi, termasuk keterbelakangan dunia pendidikan sebagaimana termanifestasi dalam praktik pendidikan di pesantren tradisional saat itu. Artinya, proses belajar-mengajar bukan hanya diselenggarakan dalam suasana penuh kegembiraan, namun pada saat bersamaan ilmu yang diperoleh itu juga harus diamalkan dan dipraktikkan dalam kehidupan, sehingga mampu menggerakkan perubahan

18 Amir Hamzah Wirjosukarto, Pembaharuan pendidikan... hlm. 56. dan kemajuan kehidupan sosial. Pun, ilmu bukan hanya untuk dirinya, tapi difungsikan untuk memperbaiki kehidupan sosial. Secara eksplisit ini ditekankan pada tujuan nomor 2 (dua), yaitu memperkembangkan cara hidup sesuai pemahaman agama Islam yang menggembirakan dan berkemajuan.

Membaca kembali tujuan pendidikan Muhammadiyah di atas dengan tinjauan zamannya, awal abad ke-20, jelas itu suatu lompatan besar yang jauh melampaui zamannya. Saat itu polarisasi dan hirarki masyarakat begitu terbuka dan tujuan pendidikan mencerminkan hal itu. Golongan santri yang dikenal religius pendidikan anak-anaknya berpusat di pesantren dan orientasi keilmuannya berkiblat ke Mekah, sedangkan golongan priyayi yang dikenal sekuler menyekelohkan anak-anaknya ke sekolah Belanda dan menjadikan Nederland (Belanda) sebagai kiblat keilmuannya.

Tujuan pendidikan di pesantren semata-mata menjadi ahli agama, sedangkan tujuan pendidikan di sekolah Belanda untuk menguasai keterampilan hidup yang diperlukan untuk memasuki kehidupan modern. Dengan kata lain, orang yang nyantri di pesantren diajari ilmu-ilmu umum-sekuler, sedangkan yang sekolah di sekolah Belanda-Barat hanya dibekali ilmu sekuler tanpa diajari agama. Dualisme sistem pendidikan inilah yang pada urutannya menghasilkan tatanan masyarakat yang dikotomis, terpecah belah antara golongan santri yang religius dan golongan priyayi yang sekuler. Salah satu alasan kehadiran pendidikan Muhammadiyah adalah untuk mencairkan dikotomi masyarakat itu. Oleh karena itu tujuan pendidikan Muhammadiyah untuk melahirkan kyai berkemajuan dan ulama intelektual/intelektual ulama sudah tepat.

Beralih ke perbincangan era perumusan formal. Perlu dicatat bahwa perumusan formal tujuan pendidikan Muhammadiyah pada dasarnya merupakan usaha untuk memahami dan mengaktualkan kembali cita-cita pendidikan yang telah ditorehkan dan diperjuangkan Kyai Dahlan sebagai pendiri organisasi. Ini artinya, perumusan formal masih memiliki garis kesinambun- 
gan dengan ide-ide sang pendiri, jadi bukan sesuatu yang seolah berdiri sendiri.

Secara ringkas, tujuan pendidikan Muhammadiyah dari masa-masa sudah ditampilkan tabel 2. Dari situ dapat dibaca bahwa dalam era perumusan formal, konsep menjadi "manusia Muslim" disebutkan secara eksplisit, kecuali rumusan Betawi yang menyebut "menjadi orang Islam yang berkobar-kobar semanagatnya". Konsep manusia Muslim senafas dengan istilah "Kyai" dalam pandangan Kyai Dahlan. Sedangkan penjelasan dan penjabaran dari konsep manusia Muslim, seperti kalimat: "berakhlak mulia, cakap, percaya kepada diri sendiri", itu senada dengan konsep "berkemajuan" dalam pandangan Kyai Dahlan. Terakhir, konsep "berguna bagi masyarakat dan Negara", satu tarikan nafas dengan pandangan Kyai Dahlan: aja kesel-kesel anggonmu nyambut gawe kanggo Muhammadiyah. Karena menurut Kyai Dahlan bekerja untuk Muhammadiyah itu adalah berjuang untuk kemajuan masyarakat dan kemajuan kehidupan sosial, bukan untuk memuliakan pimpinan ataupun memperkaya diri.

Dari uraian di atas dapat diketahui titik-titik yang menghubungkan tujuan pendidikan dalam pandangan Kyai Dahlan dengan rumusan formal tujuan pendidikan Muhammadiyah. Sedikitnya ada tiga tali yang menghubungkan keduanya, yaitu religiusitas (kyai-manusia Muslim), pertumbuhan pribadi secara optimal (kemajuan-berakhlak, cakap, percaya diri) dan berguna (bermanfaat-berfungsi-pragmatis) atau mengamalkan agama dan ilmu pengetahuan untuk memahami dan memecahkan kehidupan sosial sehingga ada kemajuan masyarakat.

Rumusan terbaru, "terbentuknya manusia pembelajar ...." lebih dekat dengan tujuan persyarikatan Muhammdiyah tahun 1921: "Memajukan dan menggembirakan pengajaran dan pelajaran agama Islam...'. Konsep ini lebih menekankan pada proses (instrumental) untuk mencapai tujuan akhir pendidikan.

\section{Tabel 2. Dinamika Tujuan Pendidikan dari Masa ke Masa}

Tahapan Tujuan Pendidikan Muhammadiyah

\footnotetext{
Tujuan pendidikan menurut KH Ahmad Dahlan:

"Dadiyo kyai sing kemajuan, lan aja kesel-kesel anggonmu nyambut gawe

Pra-perumusan $\begin{aligned} & \text { kanggo Muhammadiyah". } \\ & \text { Menjadi ulama yang berkemajuan (ulama-intelektual), dan tanpa kenal }\end{aligned}$ lelah beramal (bekerja) bagi Muhammadiyah (kemajuan kehidupan sosial).

Tujuan Muhammadiyah Era KH Ahmad Dahlan

Rumusan 1914:

Hendak menyebarkan pengajaran agama Islam kepada penduduk bumi putera di dalam residensi Jogjakarta dan hendak memajukan agama Islam kepada anggota-anggotanya

Rumusan 1921:

Perum us a Formal

1. Memajukan dan menggembirakan pengajaran dan pelajaran agama Islam di Hindia Nederland.

2. Memajukan dan menggembirakan cara kehidupan sepanjang kemauan agama Islam kepada Lid-lidnya (segala sekutunya).
} 


\begin{tabular}{|c|c|}
\hline Tahapan & Tujuan Pendidikan Muhammadiyah \\
\hline & $\begin{array}{l}\text { Rumusan Betawi (Jakarta) 1936: } \\
\text { 1. Menggiring anak-anak Indonesia menjadi orang Islam yang } \\
\text { berkobar semangatnya dengan khusyuknya, pekertinya halus lagi } \\
\text { cerdas otaknya. } \\
\text { 2. Badannya sehat, tegap bekerja } \\
\text { 3. Hidup tangannya mencari rezeki sehingga kesemuanya itu } \\
\text { memberi faedah yang besar dan berharga tinggi bagi dirinya dan } \\
\text { juga bagi masyarakat hidup bersama. }\end{array}$ \\
\hline & $\begin{array}{l}\text { Rumusan Pekajangan (Pekalongan) 1954: } \\
\text { Membentuk manusia Muslim berakhlak mulia, cakap, percaya pada } \\
\text { diri sendiri dan berguna pada masyarakat }\end{array}$ \\
\hline & $\begin{array}{l}\text { Rumusan Ujungpandang 1971: } \\
\text { Terwujudnya manusia Muslim berakhlak mulia, cakap, percaya } \\
\text { kepada diri sendiri dan berguna bagi masyarakat dan negara. }\end{array}$ \\
\hline & $\begin{array}{l}\text { Rumusan 1985: } \\
\text { Terwujudnya manusia Muslim yang bertaqwa, berakhlak mulia, } \\
\text { percaya kepada diri sendiri, cinta tanah air dan berguna bagi } \\
\text { masyarakat dan Negara, beramal menuju terwujudnya masyarakat } \\
\text { utama, adil dan makmur yang diridhai Allah SWT. }\end{array}$ \\
\hline
\end{tabular}

Sumber: Diolah dan dikembangkan penulis dari berbagai sumber.

\section{Dinamika Tujuan Pendidikan Nasional}

Ruang gerak dakwah Muhammadiyah tidak berada di ruang hampa, tetapi berlansung di dalam dan menghujam kuat di bumi Indonesia. Derap langkah pendidikan nasional Indonesia beserta dinamika masyarakatnya senantiasa menjadi salah satu pertimbangan Muhammadiyah dalam menentukan langkahnya, tidak terkecuali ketika merumuskan tujuan pendidikan. Hanya saja, pertanyaannya adalah apakah tujuan pendidikan Muhammadiyah selalu beriringan dan mengikuti dinamika tujuan pendidikan nasional? Atau, Muhammadiyah memiliki pertimbangan lebih mandiri dalam merumuskan tujuan pendidikannya. Untuk mengetahui hal itu, mesti melihat tujuan pendidikan Muhammadiyah dalam konteks pendidikan nasional.

Setelah menghirup udara kemerdekaan hingga saat ini, pendidikan nasional sudah tiga kali merumuskan tujuan pendidikan nasionalnya, yaitu rumusan 1950 (orde lama), 1989 (orde baru), dan 2003 (orde reformasi) sebagaimana tersaji pada tabel 3. Berdasarkan tahun-tahun penetapannya dapat disimpulkan bahwa setiap pergantian orde berupaya menghadirkan Undang-undang pendidikan baru dan merumuskan kembali tujuan pendidikan nasionalnya. Ini artinya perubahan kontstalasi politik nasional memberi urunan besar bagi desakan untuk mengubah tujuan pendidikan. Hal ini tidak mengejutkan, karena warna kebijakan pendidikan memang banyak diwarnai oleh pemerintah/rezim yang tengah berkuasa. 
Tabel 3. Dinamika Tujuan Pendidikan Nasional

\begin{tabular}{|c|c|c|}
\hline No. & Undang-undang & Tujuan Pendidikan Nasional \\
\hline 1. & UU No.4/1950 & $\begin{array}{l}\text { Tujuan pendidikan dan pengajaran ialah membentuk } \\
\text { manusia susila yang cakap dan warganegara } \\
\text { yang demokratis serta bertanggungjawab tentang } \\
\text { kesejahteraan masyarakat dan tanah air. }\end{array}$ \\
\hline 2. & UU No.2/1989 & $\begin{array}{l}\text { Pendidikan nasional bertujuan mencerdaskan } \\
\text { kehidupan bangsa dan mengembangkan manusia } \\
\text { Indonesia seutuhnya, yaitu manusia Indonesia yang } \\
\text { beriman dan bertaqwa terhadap Tuhan Yang Maha } \\
\text { Esa dan berbukti pekerti luhur, memiliki pengetahuan } \\
\text { dan keterampilan, kesehatan jasmani dan rohani, } \\
\text { kepribadian yang mantap dan mandiri serta rasa } \\
\text { tanggung jawab kemasyarakatan dan kebangsaan. }\end{array}$ \\
\hline 3. & UU No. $20 / 2003$ & $\begin{array}{l}\text { Pendidikan nasional berfungsi mengembangkan dan } \\
\text { membentuk watak serta kepribadian bangsa yang } \\
\text { bermartabat dalam rangka mencerdaskan kehidupan } \\
\text { bangsa, bertujuan untuk berkembangnya potensi } \\
\text { seluruh peserta didik agar menjadi manusia yang } \\
\text { beriman dan bertaqwa kepada Tuhan Yang Maha } \\
\text { Esa, berakhlak mulia, sehat, berilmu, cakap, kreatif, } \\
\text { mandiri dan menjadi warganegara yang demokratis } \\
\text { dan bertanggungjawab. }\end{array}$ \\
\hline
\end{tabular}

Eksistensi Muhammadiyah berada dalam naungan Negara Indonesia. Namun yang menarik adalah ketika merumuskan tujuan pendidikan, Muhammadiyah tidak serta merta mengikuti perubahan tujuan pendidikan nasional. Dari tabel 2 di atas, diketahui bahwa rumusan tujuan pendidikan Muhammadiyah pasca kemerdekaan sudah berlangsung tiga kali, yaitu 1954, 1971, dan 1985. Dilihat dari urutan waktuanya, hanya tujuan pendidikan 1954 yang agak berdekatan dengan tujuan pendidikan nasional 1950. Sedangkan rumusan pendidikan 1971 dan 1985 sama sekali tidak beriringan dengan dengan tujuan pendidikan nasional 1989 maupun 2003. Hal ini menunjukkan fenomena yang sungguh menarik, karena dalam merumuskan tujuan pendidikan, Muhammadiyah cenderung independen dan tidak begitu terpengaruh dengan hiruk pikuk perubahan tujuan pendidikan nasional.

Sebagaimana dijelaskan di atas, tujuan pendidikan yang agak berdekatan dan hampir beriringan adalah tujuan pendidikan nasional 1950 dan tujuan pendidikan 1954. Masa ini bangsa Indonesia tengah mengalami pergolakan, sehingga ada keinginan kuat dari elemen-elemen bangsa untuk menyatukan langkah, di antaranya adalah langkah dalam pendidikan. Dan, desakan dari pemerintah maupun intern Muhammadiyah untuk mensinergikan atau mendekatkan antara tujuan pendidikan nasional dan tujuan pendidikan Muhammadiyah cukup kuat. Namun setelah melalui permusyawaratan yang cukup alot, upaya itu tidak berhasil. Ini terlihat dari perbedaan antara konsep "manusia susila" yang dipegang oleh pemerintah dengan konsep "manusia muslim yang berakhlak mulia" menjadi tujuan pendidikan Muhammadiyah.

Dari pergumulan itu dapat ditarik interpretasi bahwa baik tujuan pendidikan nasional 1950 maupun tujuan pendidikan Muhammadiyah 1954 sebenarnya memi- 
liki titik persamaan, yaitu menekankan pada pembentukan manusia yang bermoral luhur. Hanya saja ada perbedaan penekanan dalam artikulasi rumusannya. Tujuan pendidikan nasional lebih menekankan pada konsep moral yang bercorak kebangsaan, kalau bukan malah kejawaan. Sedangkan tujuan pendidikan Muhammadiyah menekankan pada moral yang berakar/bersumber pada ajaran agama Islam, lebih berdimensi religius. Namun perlu ditekankan bahwa pemahaman keagamaan yang dibangun Muhammadiyah adalah pemahaman Islam berkemajuan dan mampu memperkuat nilai-nilai kebangsaan, sehingga perbedaan sumber nilai moral itu bukanlah saling bertentangan tetapi memperkaya wacana pengembangan manusia bermoral itu sendiri. ${ }^{19}$

Bila dibaca secara lebih seksama, rumusan tujuan pendidikan Muhammadiyah 1971 dan 1985 memiliki garis kesinambungan sekaligus konsisten dengan rumusan tujuan pendidikan sebelumnya. Titik kesinambungan itu terlihat pada konsep "terbentuknya manusia Muslim yang berakhlak mulia". Sementara itu, tujuan pendidikan nasional mengalami pergeseran dan perubahan penekanan. Tujuan pendidikan nasional 1950 menekankan pada susila (moral), tahun 1989 menekankan dimensi kecerdasan, dan tahun 2003 kembali menekankan pada watak atau moral. Data-data ini menunjukkan bahwa dalam merumuskan tujuan pendidikannya, Muhammadiyah relatif mandiri dan lebih menekankan pada dimensi akhlak mulia sebagai manifestasi dari pemahaman keagamaannya.

\section{Corak Tujuan Pendidikan Muhammadi- yah}

Setelah menjelaskan pergumulan $\mathrm{Mu}-$ hammadiyah dalam merumuskan tujuan pendidikannya di tengah konstelasi pen-

19 Diyah Kumalasari, Kajian konsep pendidikan karakter menurut KH Ahmad Dahlan dan Ki Hadjar Dewantara: Suatu refleksi historis cultural. Disertasi Universitas Negeri Yogyakarta, 2012. didikan nasional, langkah selanjutnya adalah menafsirkan corak tujuan pendidikan Muhammadiyah dengan kerangka referensi teori pendidikan modern. Di atas, pada landasan teori, dipaparkan ragam tujuan pendidikan dalam pandangan tiga teori pendidikan modern; esensialis, perenialis, dan progresif. Teori pendidikan esensialis cenderung konservatif dan bersifat tradisional, karena berupaya mempertahankan nilai-nilai luhur yang telah bertahan lama dalam kehidupan masyarakat. Sosok pribadi ideal menurut teori esensialis adalah manusia tradisionalis, yang menjunjung tinggi nilai-nilai tradisi yang telah menghujam kuat dalam masyarakat.

Teori pendidikan perenialis berorientasi regersif, ingin kembali pada idea-idea besar yang dirumuskan oleh tokoh-tokoh Abad Pertengahan, seperti Thomas Aquinas (1225-1274 M). Sosok manusia ideal yang dicita-citakan kaum perenialis adalah manusia rasional yang memiliki intelektualitas tinggi. Manusia rasional yang mampu menangkap konsep-konsep atau idea-idea besar yang telah dirumuskan oleh tokoh-tokoh Abad Pertengahan.

Terakhir, teori pendidikan progresif yang beroientasi pada kemajuan (progress) kehidupan sosial. Sosok pribadi idaman menurut teori ini adalah manusia inteligen yang mampu memecahkan permasalahan yang dihadapi dirinya maupun masyarakanya. Berbeda dengan kaum esensialis berlandaskan pada tradisi, maupun kaum perenialis yang berpegah teguh pada ideaidea besar, kaum progresif berpijak pada pengalaman sebagai pilar utama untuk memecahkan masalah kehidupan.

Berkaca pada ketiga teori pendidikan modern di atas, tujuan pendidikan Muhammadiyah lebih dekat dengan teori pendidikan progresif. Ini dapat ditunjukkan dari konsep-konsep berikut: "kyai sing berkemajuan", “aja kesel-kesel anggomu nyambut gawe kanggo Muhammadiyah", "memajukan dan menggembirakan cara kehidupan", "berguna bagi masyarakat", dan lain-lain. Meskipun tujuan pendidikan Muhammadiyah berorientasi dan lebih dekat dengan 
teori pendidikan progresif, namun harus dicatat bahwa fondasi pendidikan Muhammadiyah adalah religius, yaitu Islam yang berkemajuan. Sedangkan progresivisme bercorak sekular. Oleh karena itu, secara ringkas dapat disimpulkan bahwa tujuan pendidikan Muhammadiyah bercorak progresif religius.

\section{KESIMPULAN}

Dari seluruh uraian di atas, secara ringkas dapat ditarik tiga simpulan. Pertama, tujuan pendidikan Muhammadiyah mengalami beberapa kali perubahan yang se- cara garis besar dapat dibagi menjadi era pra-perumusan dan era perumusan formal. Beberapa kali modifikasi yang dilakukan masih menunjukkan titik kontinuitas dengan idea pendidikan $\mathrm{KH}$ Ahmad Dahlan. Kedua, dalam merumuskan tujuan pendidikan, Muhammadiyah relatif mandiri ketika diperhadapkan dengan rumusan tujuan pendidikan nasional. Ketiga, dari sudut teori pendidikan modern, corak tujuan pendidikan Muhammadiyah lebih dekat dengan teori pendidikan progresif, namun karena fondasinya religius, maka corak pendidikan Muhammadiyah adalah progresif religius.

\section{DAFTAR PUSTAKA}

Ali, Mohamad. Paradigma pendidikan berkemajuan: Teori dan praksis pendidikan progresif religius KH Ahmad Dahlan. Yogyakarta: Suara Muhammadiyah, 2016.

Al Jumbulati, Ali. Perbandingan pendidikan Islam. Jakarta: Rineka Cipta, 1994.

Assegaf, Abd. Rachman. Aliran pemikiran pendidikan Islam. Jakarta: Rajawali Pers, 2013.

Brameld, Theodore. Philosophies of education in cultural perspective. New York \& London, Holt-Rinehart-Winston.

Brubacher, John S. Modern philosophies of education. New York-London-Toronto: McGraw-Hill Book Company, 1969.

Barnadib, Imam. Filsafat pendidikan: Pengantar mengenai sistem dan metode. Yogyakarta: Andi Offset Yogyakarta, 1994.

. Beberapa hal tentang pendidikan. Yogyakarta: Studing, 1982.

Barnadib, Sutari Imam. Pengantar ilmu pendidikan sistematis. Yogyakarta: Andi Offset, 1993.

Crijns dan Reksosiswojo, Pengantar di dalam praktik pengajaran dan pendidikan 4. Jakarta: Noordhoff-Kolff, 1952.

Fakhruddin, A.R. Muhammadiyah menuju masa mendatang. Yogyakarta: Persatuan, 1985.

Gottschalk, Louis. Mengerti sejarah (terjemahan: Nuhroho Notosusanto), Jakarta: UI Press, 2008.

Knight, George R. Issues and alternative in educational philosophy. Michigan: Andrews University Press, 1982.

Kuntowijoyo, metodologi sejarah, Yogyakarta: Tiara Wacana, 2003.

Kartodirdjo, Sartono. Pendekatan ilmu sosial dalam metodologi sejarah, Jakarta: Gramedia, 1992.

Kumalasari, Diyah. Kajian konsep pendidikan karakter menurut KH Ahmad Dahlan dan Ki Hadjar Dewantara: Suatu refleksi historis cultural. Disertasi Universitas Negeri Yogyakarta, 2012. 
PROFETIKA, Jurnal Studi Islam, Vol. 17, No. 1, Juni 2016: 43-56

Pasha, Musthafa Kamal dan Ahmad Adaby Darban. Muhammadiyah sebagai gerakan Islam dalam perspektif historis dan ideologis. Yogyakarta: LPPI, 2000.

Quthb, Muhammad . Sistem pendidikan Islam (Terjemahan: Salman Harun). Bandung: Al-Maarif, 1984.

Ridla, Muhammad Jawad . Tiga aliran utama teori pendidikan Islam (Terjemahan: Mahmud Arif). Yogyakarta: Tiara Wacana, 2002.

Saifullah, Ali. Pendidikan pengajaran dan kebudayaan. Surabaya: Usaha Nasional, 1982.

Sjamsuddin, Helius. Metodologi sejarah, Yogyakarta: Ombak, 2012.

Shobron, Sudarno dkk. Studi Kemuhammadiyahan. Surakarta: LPIK UMS, 2014.

Wirjosukarto, Amir Hamzah. Pembaharuan pendidikan dan pengajaran Islam yang diselenggarakan oleh pergerakan Muhammadiyah. Yogyakarta: Penyelenggara publikasi pebaharuan pendidikan/pengajaran Islam, 1962. 